\title{
Interaksi Umat Islam Indonesia Terhadap Lansia (Studi Living Qur'an)
}

\author{
(Interaction of Indonesian Muslims towards the Elderly (Study of the Living \\ Qur'an))
}

\section{Mohammad Rohmanan}

UIN Maulana Malik Ibrahim Malang, Indonesia

mohammadrohmanan@gmail.com

DOI: $10.29240 /$ alquds.v5i2.2525

Submitted: 2021-02-21 | Revised: 2021-08-16 | Accepted: 2021-09-06

\begin{abstract}
Through the Qur'an and Hadith, Islam upholds the honor of the elderly. The attitudes, words, and deeds of the prophet Muhammad SAW were the actualization of the values of the Qur'an, so that he was dubbed "the walking Qur'an". Rasulullah SAW's exemplary example becomes the prototype of the concept of living al-Qur'an which is the values of Qur'an that are understood, and practiced collectively by Muslims community, then become local wisdom. This paper analyzes the elderly in the perspective of the living Qur'an of Indonesian Muslims. In processing the data in this study, the authors used thematic tafseer methods and living quran. From this study the authors found that the concept of living quran Indonesian society in terms of treatment of the elderly is very good, it is manifested in some local wisdom of Indonesian society towards the elderly, such as the use of special language for the elderly, kissing the hands of the elderly, bowing when walking in front of the elderly and and the ritual of ziarab makam lelubur.
\end{abstract}

Keyword: qur'an; interpretation; thematic interpretation; thematic tafseer; living quran; elderly

Abstrak. Melalui al-Qur'an dan Hadis, Islam menjunjung tinggi kehormatan lansia.Sikap, sabda dan perbuatan Rasulullah SAW merupakan aktualisasi nilai-nilai al-Qur'an, sehingga beliau digelari “al-Qur'an berjalan”. Kemudian keteladanan Rasulullah SAW tersebut menjadi prototipe konsep living al-Qur'an, yaitu ajaran al-Qur'an yang dipahami, lalu dipraktikkan secara kolektif oleh umat muslim, sehingga menjadi kearifan lokal. Tulisan bertujuan menganalisis interaksi umat muslim Indonesia terhadap lansia dalam perspektif Living Qur'an. Dalam mengolah data, pada penelitian ini penulis menggunakan metode tafsir tematik dan living quran. Temuan yang diperoleh penulis dari penemuan ini adalah konsep living quran masyarakat Indonesia dalam hal perlakuan terhadap lansia sangat bagus, hal itu terwujud dalam beberapa kearifan lokal masyarakat Indonesia terhadap lansia, seperti penggunaan bahasa khusus terhadap lansia, mencium tangan 
lansia, membungkukan badan ketika berjalan di depan lansia, dan ritual ziarah makam leluhur.

Keyword : quran, tafsir, tafsir tematik, living quran, lansia, tua.

\section{Pendahuluan}

Islam adalah agama kasih sayang. Melalui al-Qur'an sebagai kitab sucinya, Islam mengangkat kedudukan manusia sebagai makhluk yang mulia. Termasuk di dalamnya adalah memuliakan orang yang lanjut usia. Rasulullah SAW merupakan teladan dalam mengaplikasikan nilai-nilai al-Qur'an dalam kehidupan manusia. Gerak-geriknya memberi contoh kepada kita tentang bagaimana harus berinteraksi dengan orang yang lanjut usia.

Bagaimanapun juga orang lansia memiliki keadaan yang berbeda dengan orang lain yang usianya berbeda dengan dia. Sehingga dalam ranah sosial seorang lansia mebutuhkan perlakuan khusus sehingga dia dapat hidup secara nyaman di tengah masyarakat. Jika ini terwujud maka suasana sosial yang indah akan terwujud dalam suatu masyarakat atau komunitas.

Bangsa Indonesia dikenal sebagai bangsa yang ramah dibanding dengan bangsa-bangsa lain ${ }^{1}$. Dari sini dirasa penting untuk mengkaji kebudayaan dan kearifan lokal dari bangsa Indonesia, khususnya yang berkenaan dengan interaksi mereka terhadap orang lanjut usia (lansia). Karena kebudayaan yang positif seperti ini perlu disosialisasikan terhadap generasi muda Indonesia agar tetap lestari di tengah terjadinya sentuhan mereka terhadap berbagai macam budaya yang masuk.

Tulisan ini bertujuan menganalisis interaksi masyarakat Indonesia terhadap lansia yang merupakan perwujudan nilai-nilai yang terdapat dalam alQuran terkait ajaran-ajaran yang berhubungan dengan interkasi terhadap lansia.

Pada penelitian-penelitian sebelumnya penelitian tentang lansia berkisar tentang yang terjadi pada diri lansia. Seperti senam lansia yang diteliti oleh $\mathrm{M}$ Yanti dkk. ${ }^{2}$, kecemasan pada diri lansia kekhawatiran pada lansia yang diteliti oleh al-Mubarroh ${ }^{3}$, dan depresi lansia yang diteliti oleh Sucipto $\mathrm{dkk}^{4}$. Terdapat juga

1 "Ramah, Identitas Indonesia di Mata Dunia," diakses 3 September 2021, https://www.goodnewsfromindonesia.id/2018/07/25/ramah-identitas-indonesia-di-matadunia.

${ }^{2}$ Meyi Yanti, Alkafi Alkafi, dan Defi Yulita, "Senam Lansia terhadap Tekanan Darah pada Lansia Hipertensi," JIK (Jurnal Ilmu Kesehatan) 5, no. 1 (2021): 44-52.

${ }^{3}$ Nadya Ristamida Al Mubarroh, Indra Himawan Susanto, dan Yetty Septiani Mustar, "Aktivitas fisik dan aspek kekhawatiran lansia pada masa pandemi Covid-19," Altius: Jurnal Ilmu Olahraga dan Kesehatan 10, no. 1 (2021): 99-111.

${ }^{4}$ Sucipto Sucipto dan Fajar Rinawati, "Perbedaan Depresi Lansia di Pondok Lansia dan Lansia di Posbindu," Jurnal Ilmiah Permas: Jurnal Ilmiah STIKES Kendal 11, no. 1 (2021): 43-48. 
penelitian tentang konsep ibadah haji bagi lansia yang diteliti oleh Rosidin $\mathrm{dkk}^{5}$. Penulis belum menemukan penelitian seputar lansia yang memfokuskan kepada interaksi terhadap lansia.

Seputar tafsir mawdu'i atau tafsir tematik, terdapat banyak penelitian seperti al-Tafsir al-Mawdu'i li al-Qur'an al-Karim oleh Ahmad Sayyid al-Kumiy ${ }^{6}$ yang merupakan rujukan di bidang tafsir mawdu'i setelahnya; Pendidikan Anak Usia Dini dalam kajian tafsir mawdu'i oleh Maulidah ${ }^{7}$; dan makna dan manfaat tafsir mauwdu'i oleh Maladi'. Penulis belum menemukan kajian tafsir mawdu'i yang digabungkan dengan living quran seputar interaksi terhadap lansia.

Adapun seputar living quran, terdapat banyak penelitian seperti $M$ Mansur ${ }^{9}$ dan Aji dkk yang mengkaji tentang objek dan metodologi Living Quran dan $\mathrm{Hadis}^{10}$; Salafudin yang meneliti tentang studi living quran terhadap tradisi pembacaan surat Waqi'ah pada Pondok Pesantren darul Falah Tulungagung ${ }^{11}$; dan tradisi pembacaan Yasin 41 yang diteliti oleh Simamora ${ }^{12}$. Sedangkan pada artikel ini penulis akan menfokuskan pada living quran interaksi terhadap lansia pada umat muslim di Indonesia.

Dalam mengolah data, penelitian ini menggunakan metode tafsir maudu'i dan living quran. Metode tafsir mawdu' ${ }^{13}$ : digunakan untuk menganalisa ayat-ayat al-Quran yang berhubungan dengan interaksi dengan lansia. Sedangkan metode living quran digunakan untuk menganalisa nilai-nilai al-Quran terkait interaksi

5 "Bina'al-Fiqh al-Hajj al-Muyassar," diakses 3 September 2021, https://scholar.google.co.id/citations?view_op=view_citation\&hl=id\&user=XGUYN5YAAAA J\&citation_for_view=XGUYN5YAAAAJ:_d1gkVwhDpl0C.

${ }^{6}$ Ahmad Sayyid Kumi (al) dan Muhammad Ahmad Yusuf Qasim (al), al-Tafsir al-Mawdu'i li al-Quran al-Karim, 1982.

${ }^{7}$ Evi Maulidah, "Pendidikan Anak Usia Dini Menurut Al-Qur'an Dalam Kajian Tafsir Maudhu'i," Childhood Education: Jurnal Pendidikan Anak Usia Dini 2, no. 2 (2021): 170-82.

${ }^{8}$ Yasif Maladi, Makna dan Manfaat Tafsir Maudhu'i (Prodi S2 Studi Agama-Agama UIN Sunan Gunung Djati Bandung, 2021).

${ }^{9}$ M. Mansyur, ed., Metodologi penelitian living Qur'an \& Hadis / M. Mansyur (Yogyakarta: THPress [u.a.], 2007).

${ }^{10}$ Mujib Hendri Aji, Muhammad Zainul Hilmi, dan M. Taufiq Rahman, "The Living Qur'an as a Research Object and Methodology in the Qur'anic Studies," Jurnal Iman dan Spiritualitas 1, no. 1 (2021): 78-84.

${ }^{11}$ Ahmad Basith Salafudin, "Studi Living Qur'an: Tradisi Pembacaan Surat Al-Waqi'ah Di Pondok Pesantren Darul-Falah Tulungagung," Al-Drikra: Jurnal Studi Ilmu al-Qur'an dan al-Hadits 15, no. 1 (2021): 111-138.

12 Tia Subu Simamora, “Tradisi Pembacaan Yasin 41 Studi Living Qur'an,” Jurnal El Thawalib 2, no. 2 (2021): 1-14.

${ }^{13}$ Kumi (al) dan Qasim (al), al-Tafsir al-Mawdu'i li al-Quran al-Karim, 23. 
dengan lansia yang telah diaplikasikan oleh masyarakat Indonesia sehingga menjadi sebuah kearifan lokal dari masyarakat itu sendiri.

Secara bahasa living quran berasal dari susunan bahasa Inggris yang bermakna Al-Qur'an yang hidup. Adapun definisi living quran secara istilah, terdapat beberapa pernyataan. Nama yang paling muncul dalam kajian living quran adalah M Mansyur. Ia menyatakan bahwa living quran adalah "fenomena yang hidup di tengah masyarakat Muslim terkait dengan Qur'an ini sebagai objek studinya." ${ }^{14}$ Oleh karena itu, kajian tentang Living Qur'an dapat diartikan sebagai kajian tentang "berbagai peristiwa sosial terkait dengan kehadiran Qur'an atau keberadaan Qur'an di sebuah komunitas muslim tertentu." ${ }^{15}$ Sedangkan Syamsuddin mengatakan bahwa living quran adalah respons masyarakat terhadap teks al-Qur'an dan hasil penafsiran seseorang. ${ }^{16}$

Dengan ungkapan yang lebih sederhana, living quran merupakan kajian terhadap implementasi nilai-nilai al-Quran dari suatu masyarakat atau komunitas. Implementasi itu bisa berupa ritual, kegiatan, norma, adat, tradisi, budaya, kearifan lokal, dan sebagainya.

Definisi-definisi di atas lebih membatasi kajian living quran pada ranah komunitas atau masyarakat saja. Akan tetapi penulis lebih setuju apabila ranah kajian living quran juga bisa diterapkan pada ranah individu, baik individu itu berupa tokoh maupun bukan. Sehingga kajian living quran akan menjadi lebih luas sesuai dengan luasnya kajian al-Quran.

Sebenarnya konsep living quran sudah bukanlah hal yang baru. Pada masa awal Islam sudah terdapat salah satu sahabat yang melakukan kajian terhadap respon seseorang atau komunitas terhadap al-Qur'an. Dalam suatu hadis disebutkan ${ }^{17}$ :

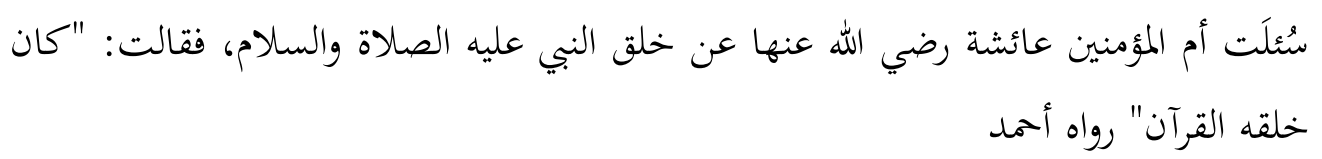

"Ummul Mu'minin 'Aisyah pernah ditanya tentang akblak Nabi SAW. Ia menjawab : Akblaknya adalah al-Qur'an" (HR Ahmad) 2007), 5 .

${ }^{14}$ M. Mansyur, dkk., Metodologi Penelitian Living Qur'an dan Hadis, (Yogyakarta: TH. Press, 158.

${ }^{16}$ Syamsudin, S., "Ranah-ranah Penelitian dalam Studi al-Qur'an dan Hadis" dalam M. Mansyur dkk., Metodologi Penelitian Living Qur'an dan Hadis, (Yogyakarta: TH. Press, 2007), 14.

${ }^{17}$ Ahmad ibn Hanbal, Musnad al-Imam Ahmad ibn Hanbal, vol. 41 (Beirut: Mu'assasah alRisalah, 1995), 148. 
Pada hadis di atas para sahabat melakukan sebuah penelitian tentang respon Nabi SAW terhadap al-Quran, di mana peneliti menggali data dengan bertanya kepada orang terdekat Nabi SAW yaitu 'Aisyah RA.

Menurut hemat penulis, kajian living quran setidaknya memiliki dua fungsi. Pertama, yaitu untuk mengetahui tingkat keberhasilan dakwah Islam dalam suatu komunitas atau masyarakat. Dengan kajian living quran seorang peneliti dapat mendapatkan gambaran seberapa jauh nilai-nilai al-Quran diterapkan dalam suatu komunitas atau masyarakat.

Kedua, yaitu sebagai sarana keteladanan dari suatu tokoh atau seseorang atas respon atau interaksinya terhadap al-Qur'an. Dimana dengan kajian living quran masyarakat mendapatkan teladan atau contoh dalam mengaplikasikan nilainilai al-Quran. Keteladanan tersebut bisa berwujud sebuah tokoh atau atau masyarakat yang telah menjalankan nilai-nilai al-Quran dalam kehidupannya.

\section{Lansia Dalam Perspektif Al-Qur'an}

\section{Analisa Linguistik}

Dalam mengungkapkan makna orang tua/ lanjut usia, Al-Qur'an menggunakan dua kata yaitu شيخ untuk laki-laki tua dan lafadz عجوز untuk perempuan tua. Lafadz شيخ terulang sebanyak 4 kali (3 kali dalam bentuk mufrad dan sekali dalam bentuk jama) sedangkan lafadz عجوز terulang sebanyak 4 kali yang kesemuanya menggunakan bentuk mufrad. Sedangkan makna lansia secara umum diungkapkan dengan lafadz ضعeضl (terulang 1 kali dalm bentuk masdar), (terulang 1 kali dalam bentuk ism fa'i), sevi (terulang 1 kali dalam bentuk jama' taksir), مستضعين (terulang 2 kali dengan bentuk jamak mudzakkar salim)

Tentang makna dari شيخ Ibnu Mandzur mengatakan dalam Lisan al-'Arab: "al-Shaykh adalah orang yang usia tuanya sudah jelas dan mulai tampak ubannya. Ada juga yang mengatakan bahwa shaykh adalah orang yang berumur 50 tahun sampai akhir umurnya; 51 sampai akhir umurnya; dan pendapat lain mengatakan rentangan umur 50-80 tahun. Jama' dari lafadz shaykh adalah ashyakh, shiykhan, shuyukh, shiyakhah, shiykhah, mashyakhah, mishyakhah, mashiykhah, mashyukha', dan mashayikh." 18

Dari pernyataan Ibnu Mandzur di atas dapat kita simpulkan bahwa orang tua/ lanjut usia memiliki 2 indikator yaitu umur dan kondisi tubuh atau fisik.

\footnotetext{
${ }^{18}$ Ibnu Manzur,. Lisan al-'Arab, (Kairo: Dar al-Ma'arif,___, jilid 7:2373.
} 
Sedangkan al-Samin al-Halabiy berpendapat bahwa shaykh adalah yang orang yang mencapai umur tua walaupun tidak beruban ${ }^{19}$. Al-Raghib al-Asfahani menambahkan bahwa lafadz shaykh mengalami perpindahan makna di mana lafadz itu juga dapat digunakan untuk menunjukkan makna orang yang memiliki banyak ilmu karena orang yang berusia tua biasanya memiliki banyak pengalaman dan pengetahuan dalam hidup ${ }^{20}$.

Sedangkan lafadz عجوز tersusun dari akar kata عجز. Tentang makna dari akar kata ini al-Raghib al-Asfahani menyatakan: “(jika dikatakan) 'ajuz al-insan artinya adalah bagian belakang dari manusia. Oleh karena itu setiap bagian terbelakang dari segala sesuatu diungkapkan dengan kata ini. Allah berfirman : ka annabum a'jazu nakblin munqa'ir (yang menggelimpangkan manusia seakan-akan mereka pokok korma yang tumbang) [QS. al-Qamar:20]. 'ajz. makna aslinya adalah terbelakang(ketinggalan) sesuatu. (sebagai contoh) busulubu 'inda 'ajz al-amri artinya adalah : ia mendapatkannya pada 'ajz al-amri (pada akhirnya). Kemudian karena perkembangan kebiasaan manusia lafadz ini dugunakan untuk mengungkapkan ketidakmampuan untuk melakukan sesuatu (lawan kata dari lafadz al-qudrah). Allah SWT berfirman (kisah dua anak Adam AS) : “a a’jaztu (apakah aku tidak bisa) menjadi seperti burung ini" [al-Maidah :31] ... perempuan tua dinamakan 'ajuz karena ia tidak mampu melakukan banyak hal. Allah berfirman : kecuali 'ajuz, (perempuan tua) yang tertinggal di belakang mereka"(al-Shaffat:135). ${ }^{21}$

Ibn Mandzur mengatakan: "kata al-'ajuz dan al-'ajuzah maknanya adalah perempuan tua renta. Kata yang terakhir (al-'Ajuzab) sangat jarang penggunaannya". ${ }^{22}$

Dari pemaparan di atas dapat dsimpulkan bahwa kata شجوز dan memiliki makna seputar umur tua dan kondisi fisik yang lemah.

\section{Kondisi Yang Dialami Oleh Lansia}

a. Kondisi Fisik

Manusia dalam keberadaannya melewati beberapa fase. Di antara ayat alQuran yang menyinggung tentang fase-fase manusia adalah berikut ini : Jilid2:309.

19 Al-Samin al-Halaby., Umdat al-Huffadz, (Beirut: Dar al-Kutub al-'Ilmiyyah, 1997)

${ }^{20}$ Al-Raghib al-Asfahani, al-Mufradat fi Gharib al-Qur'an, (Mekkah: Maktabah Mustafa Nizar al-Baz, __ jilid 1:356

${ }^{21}$ al-Asfahani, al-Mufradat fi Gharib al-Qur'an, 2:419.

22 Manzur,. Lisan al-'Arab, 32:2819. 


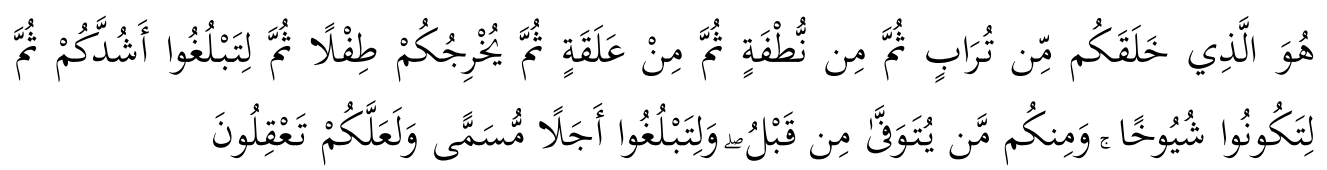

'Dialah yang menciptakan kamu dari tanah kemudian dari setetes mani, sesudah itu dari segumpal darah, kemudian dilabirkannya kamu sebagai seorang anak, kemudian (kamu dibiarkan bidup) supaya kamu sampai kepada masa (dewasa), kemudian (dibiarkan kamu bidup lagi) sampai tua, di antara kamu ada yang diwafatkan sebelum itu. (Kami perbuat demikian) supaya kamu sampai kepada ajal yang ditentukan dan supaya kamu memahami(nya) 23". (QS. Ghafir:67)

Dalam ayat di atas disebutkan bahwa fase-fase yang dilalui oleh manusia di dunia adalah sebagai berikut :

1) Fase tanah (خَخَقَكُمْ مِنْ تُرَابٍ

Pada fase ini manusia menyatu dengan alam dimana ia tak lain hanyalah bagian dari alam itu sendiri yaitu sebuah tanah. Apakah setiap orang mengalami fase ini? para pakar tafsir berbeda pendapat. Sebagian mufassir berpendapat yang mengalami fase ini hanyalah manusia pertama yaitu Adam AS karena ia diciptakan dari tanah ${ }^{24}$. Dalam surat al-A'raf disebutkan :

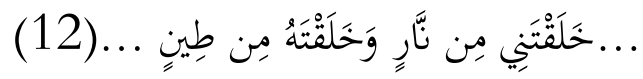

"...(iblis berkata) Engkau (Ya Allab) menciptakan aku dari api dan menciptakan dia (Adam) dari tanah" ${ }^{25}$... " (QS. Al-A'raf: 12)

Sementara beberapa pakar tafsir lain berpendapat bahwa setiap manusia mengalami fase ini. Karena sebelum menjadi sperma yang merupakan cikal bakal manusia, ia masih berupa makanan yang akan dikonsumsi oleh manusia. Yang mana pada hakikatnya setiap makanan baik -itu berupa hewan atau tumbuhan yang dimakan oleh hewan- mendapatkan nutrisi makanan dari tanah ${ }^{26}$.

2) Fase air mani (نُّنْ

23 Jajaran Penjelenggara Penterdjemah/Pentafsir Al-Qoeraan (1967), Alquran dan Terjemahnya edisi penyempurnaan (Lajnah Pentashihan Mushaf Al-Qur'an, 2019), 690-691.

${ }^{24}$ Muhammad Wahbah Al-Zuhailiy, al-Tafsir al-Munir fi al-'Aqidah wa al-Shari'ah wa alManhaj, vol. 9 (Damaskus: Dar el-Fikr, 2003), 338.

${ }^{25}$ Alquran dan Terjemahnya edisi penyempurnaan, 206.

${ }^{26}$ Fakhruddin Muhammad Razi (al), al-Tafsir al-Kabir aw Maaftih al-Ghayb, vol. 23 (Kairo: Maktabah Tawfiqiyyah, _), 79. 
Pada fase ini manusia berada di dalam tubuh orang yang akan menjadi orang tuanya nanti. Ia adalah sebuah spermatozoid dari laki-laki dan ovum dari perempuan.

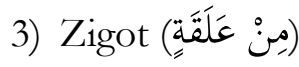

Spermatozoid dari seorang laki-laki dan ovum dari perempuan bertemu pada rahim perempuan. Dari pertemuan tersebut terbentuklah sebuah zigot. Pada fase ini manusia menyatu pada diri seorang peremuan yang bakal menjadi ibunya.

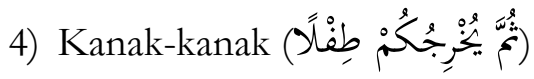

Setelah beberapa bulan menyatu dengan tubuh ibunya. Tubuh bayi mulai berpisah dari tubuh ibunya. Akan tetapi dalam segi fisik ia belum mandiri secara keseluruhan. Kondisi fisik masih dalam keadaan lemah sehingga dalam memenuhi kebutuhannya ia bergantung kepada orang tuanya.

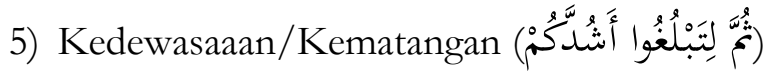

Pada fase ini manusia sudah memiliki kekuatan yang matang sehingga dalam memenuhi kebutuhannya kebanyakan ia bisa berusaha sendiri.

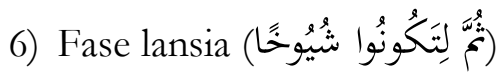

Ini merupakan fase terakhir dari kehidupan manusia di dunia. Dimana pada fase inilah manusia mengalami kematian. Dalam surat al-Hajj Allah SW'T berfirman :

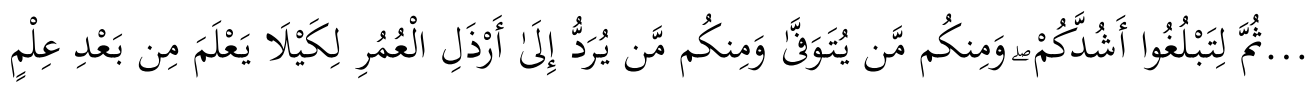

“...kemudian (dengan berangsur-angsur) kamu sampailah kepada kedewasaan, dan di antara kamu ada yang diwafatkan dan (adapula) di antara kamu yang kembalikan kepada umur yang hina, supaya dia tidak mengetahui lagi sesuatupun yang dabulunya telah diketahuinya (pikun)..." " (QS. Al-Hajj:5).

Dalam ayat di atas disebutkan bahwa setelah masa kematangan atau kedewasaan (ashudda) manusia mengalami kematian. Adapun manusia yang tidak mengalami kematian, maka sebagian dari mereka akan dikembalikan seperti umur

27 Alquran dan Terjemahnya edisi penyempurnaan, 472. 
semula dimana dia akan mengalami ketidaktahuan terhadap apa-apa yang telah diketahuinya sebelumnya ${ }^{28}$.

Dalam surat yasin disebutkan bahwa manusia yang diberi tambahan umur setelah dewasa maka Allah SWT akan membalik keadaannya. Allah berfirman SWT :

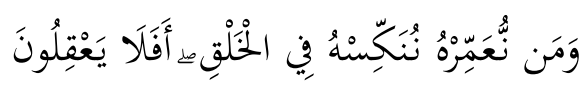

"Dan barangsiapa yang Kami panjangkan umurnya niscaya Kami kembalikan dia kepada kejadian(nya). Maka apakah mereka tidak memikirkan?” (QS. Yasin:68)

Dalam surat al-Rum al-Quran menyebut fase balita dan fase lansia dengan sebutan yang sama, yaitu dlu'f(ضع) yang bermakna lemah. Allah berfirman:

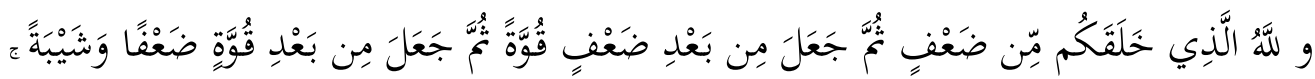

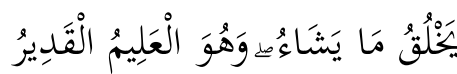

"Allah, Dialah yang menciptakan kamu dari kelemahan, kemudian sesudah kelemahan itu Dia menjadikan kekuatan, kemudian sesudah kekuatan itu Dia menjadikan kelemahan dan beruban. Dia menciptakan apa yang dikehendaki-Nya dan Dialab Yang Maba Mengetahui lagi Maha Kuasa. ${ }^{\text {'29 }}$ (QS. AL-Rum;54).

Dari ayat di atas penulis memahami bahwa pada masa lansia ada dua keadaan yaitu kelemahan yang didalamnya termasuk lemahnya fisik dan uban.

Di dalam surat Maryam disebutkan keadaan nabi Zakariya AS ketika ia berdoa pada masa tua :

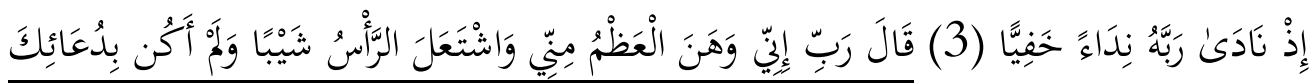

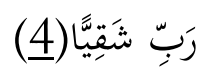

"(3) yaitu tatkala ia berdoa kepada Tubannya dengan suara yang rendah. (4) Ia berkata "Ya Tubanku, sesunggubnya tulangku telah lemah dan kepalaku telah dipenubi uban, dan aku belum pernah kecewa dalam berdoa kepada Engkau, ya Tubanku. "30 (QS. Maryam:34)

Dalam ayat di atas disebutkan bahwa beberapa keadaan nabi Zakariya ketika berdoa yang mana usianya sudah memasuki masa tua. Di antara keadaan

${ }^{28}$ Muhammad Sayyid Tantawi, al-Tafsir al-Wasit li al-Qur'an al-Karim, vol. 9 (Kairo: Dar alSa'adah, 2007), 281.

29 Alquran dan Terjemahnya edisi penyempurnaan, 373.

${ }^{30} 294$. 
fisik yang beliau sebutkan adalah suara yang mulai tidak senyaring atau sekeras masa muda, kekuatan tulang yang sudah mulai melemah, dan kepala yang sudah dipenuhi dengan uban sehingga digambarkan kepalanya seperti menyala $\left({ }^{3}\right)^{31}$.

Masa lansia juga memiliki pengaruh terhadap produktifitas dan kualitas reproduksi sesorang. Sehingga kebanyakan lansia lebih utamanya perempuan sudah tidak dapat menghasilkan keturunan atau dengan kata lain mandul. Masa ini disebut sebagai masa menopause ${ }^{32}$. Masa ini dialami oleh lansia laki-laki dan perempuan. Di dalam surat Hud disebutkan:

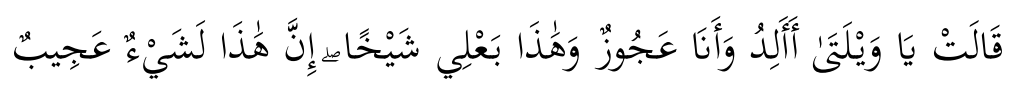

"Isterinya berkata: "Sungguh mengherankan, apakah aku akan melabirkan anak padahal aku adalah seorang perempuan tua, dan ini suamikupun dalam keadaan yang sudah tua pula? Sesunggubnya ini benar-benar suatu yang ajaib ${ }^{133}$. (QS. Hud:72)

Dalam ayat tersebut dikisabkan bahwa isteri nabi Ibrabim merasa sangat heran ketika mengetabui para Malaikat datang kepada nabi Ibrabim untuk memberi kabar gembira berupa akan labimya seorang anak yang bernama Ishaq. Yang memicu keheranannya adalah usia mereka berdua yang sudah lanjut. Karena hampir setiap orang lansia tidak bisa menghasilkan keturunan ${ }^{34}$.

\section{Kondisi Psikis}

Beberapa perubahan fisik pada lansia sedikit banyak memberikan pengaruh pada kejiwaan seorang lansia. Rasa cemas, depresi, atau putus asa mungkin muncul karena beberapa perubahan yang terjadi pada dirinya seperti tubuhnya mulai lemah atau penampilannya berubah. Sehingga mulai muncul rasa ketergantungan terhadap orang lain yang mungkin itu berupa anaknya atau orangorang dekatnya dikarenakan ia mulai lemah dalam memenuhi kebutuhankebutuhannya.

Keadaan reproduksinya yang sudah tidak produktif juga memunculkan kecemasan tersendiri. Apalagi jika ia sampai usia tersebut juga belum diberi karunia berupa keturunan dan generasi penerus yang akan melanjutkan perjuangannya dalam hidup. Dalam surat Maryam disebutkan : 2007), 71.

${ }^{31}$ Muhammad al-Qurtubiyy, al-Jami' li Abkam al-Qur'an, vol. 6 (Kairo: Dar al-Hadith, 32 Sri Winarni, Djoko Nugroho, dan Farid Agushybana, "Dasar Kesehatan Reproduksi," t.t., 12 .

\footnotetext{
33 Alquran dan Terjemahnya edisi penyempurnaan, 317.

34 al-Zuhaily, al-Tafsir al-Munir fi al-'Aqidah wa al-Shari'ah wa al-Manhaj, 6:426.
} 


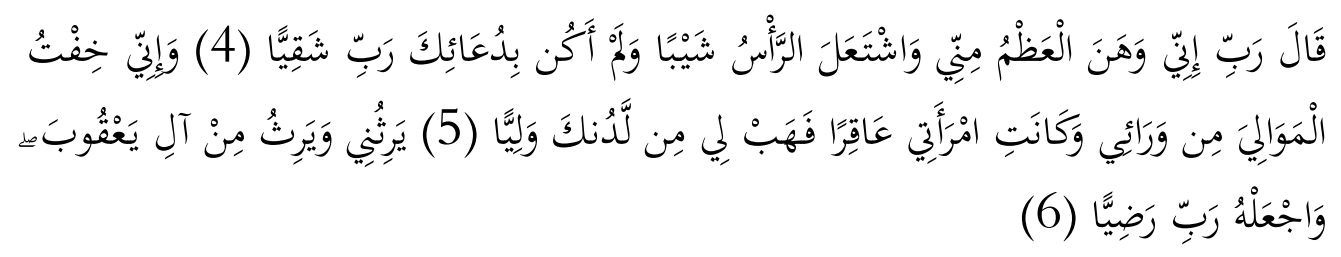

"(4) Ia berkata "Ya Tubanku, sesunggubnya tulangku telab lemah dan kepalaku telah ditumbuhi uban, dan aku belum pernah kecewa dalam berdoa kepada Engkau, ya Tuhanku. (5) Dan sesunggubnya aku khawatir terhadap mawaliku sepeninggalku, sedang isteriku adalah seorang yang mandul, maka anugerabilah aku dari sisi Engkau seorang putera, (6) yang akan mewarisi aku dan mewarisi sebahagian keluarga Ya'qub; dan jadikanlab ia, ya Tubanku, seorang yang diridhai"135. (QS. Maryam 4-6)

Dalam ayat di atas Zakaria dalam munajatnya mengadukan beberapa hal. Yang pertama ia mengadukan perubahan kondisi fisiknya. Kemudian ia mengkhawatirkan orang-orang yang akan melanjutkan urusannya sepeninggalnya karena mereka kurang ia percaya dalam menjalankan urusannya. Ia juga mengadukan keadaan isterinya yang sudah tua dan belum menghasilkan seorang keturunan. Di dalam doanya ia memohon kepada Allah SWT agar diberi keturunan sehingga ada yang mewarisi keilmuan dan kapabilitasnya serta melanjutkan perjalanan hidupnya ${ }^{36}$.

Dari sini penulis mendapatkan gambaran apa yang ada pada pikiran seorang lansia. Beban pikiran atau kesusahan yang dialami oleh lansia akan mudah mempengaruhi kondisi fisik lansia itu sendiri. Hal ini terjadi oleh nabi Ya'qub AS ketika usianya sudah lanjut sedang ia dalam kesedihan memikirkan anaknya yang bernama Yusuf AS. Al-Quran mengungkapkan hal ini sebagai berikut :

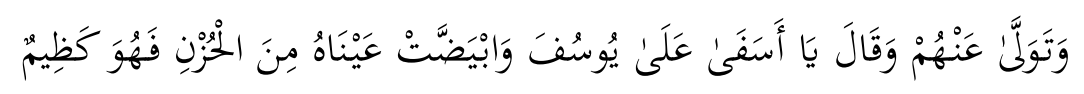

"Dan Ya'qub berpaling dari mereka (anak-anaknya) seraya berkata: "Adubai duka citaku terhadap Y usuf", dan kedua matanya menjadi putih karena kesedihan dan dia adalah seorang yang menahan amarahnya (terbadap anak-anaknya)." "'77 (QS. Yusuf:84)

Salah satu perubahan psikis seorang lansia adalah lemahnya daya pikir atau bahkan sampai pada level pikun sebagaimana disebutkan dalam al-Qur'an :

\footnotetext{
35 Alquran dan Terjemahnya edisi penyempurnaan, 294.

36 al-Zuhaily, al-Tafsir al-Munir fi al-'Aqidah wa al-Shari'ah wa al-Manhaj, 8:388.

37 Alquran dan Terjemahnya edisi penyempurnaan, 340.
} 


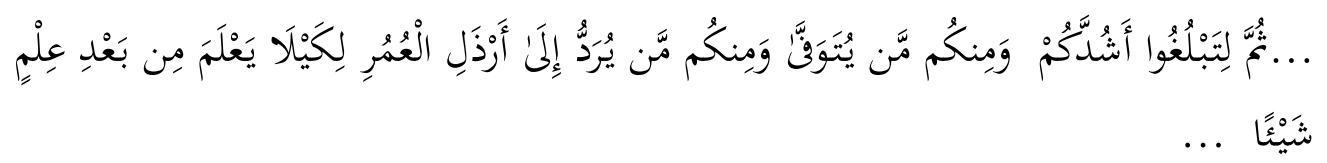

“...kemudian (dengan berangsur-angsur) kamu sampailah kepada kedewasaan, dan di antara kamu ada yang diwafatkan dan (adapula) di antara kamu yang kembalikan kepada umur yang bina, supaya dia tidak mengetabui lagi sesuatupun yang dabulunya telah diketahuinya (pikun)...” (QS. Al-Hajj:5).

Kebanyakan ahli tafsir berpendapat bahwa yang umur yang hina pada ayat di atas adalah pikun. Sementara ahli tafsir lain mengatakan bahwa itu adalah penurunan daya tangkap indera dan akal ${ }^{38}$.

\section{Perlakuan Terhadap Lansia Dalam Al-Qur'an}

Dengan kondisi fisik dan psikis yang demikian lansia patut untuk diperlakukan secara khusus sehingga mereka bisa hidup yang layak dalam kerangka aturan-aturan Islam yang berjalan.

Agama Islam mengajarkan kepada pemeluknya untuk memperlakukan mereka secara khusus. "Bukan termasuk dari golonganku orang yang tidak memuliakan orang yang berusia tua", demikian sabda Rasulullah SAW yang sering kita dengar. Dalam sebuah Rasulullah SAW bersabda :

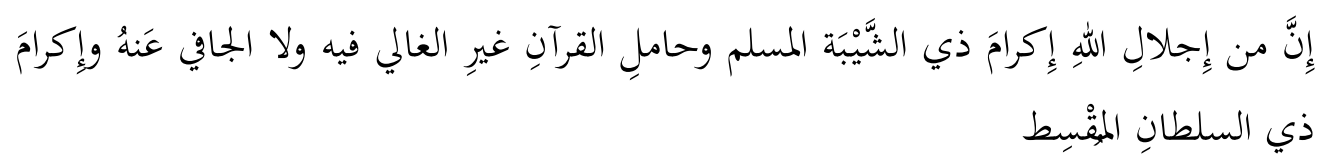

"di antara bagian dari wujud mengagungkan Allah SWT adalah memuliakan lansia yang sudah beruban, abli Quran yang tidak berlebiban dan tidak menyepelekannya, dan memuliakan pemimpin yang adil" ${ }^{39}$ (HR. Abu Dawnd)

Pada hadis di atas Rasulullah SAW ketika mennyebutkan perwujudan dari pengagungan terhadap Allah SWT, yang pertama kali disebut adalah memuliakan orang yang lanjut usia. Ini menunjukkan betapa urgen perhatian Islam terhadap lansia.

Di antara bimbingan al-Qur'an dalam memperlakukan lansia adalah sebagai berikut :

\section{Memenuhi kebutuhan lansia}

Dalam memperlakukan orang lansia dengan kondisi fisik yang lemah dan psikis yang mulai memiliki ketergantungan terhadap orang lain seperti telah

${ }^{38}$ Tantawi, al-Tafsir al-Wasit li al-Qur'an al-Karim, 9:281.

${ }^{39}$ Abu Dawud, Sunan Abi Dawnd,vol.5 (Beirut: Dar Ibn Hazm, 1997), 112 hadis no.4843. 
disebut di atas, al-Qur'an memberi contoh betapa urgen untuk membantu memenuhi kebutuhan mereka. Hal ini bisa ditangkap pada kisah nabi Musa AS di surat al-Qasas :

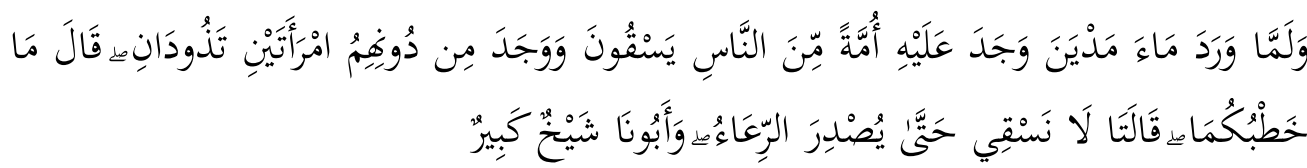

'Dan tatkala ia sampai di sumber air negeri Madyan ia menjumpai di sana sekumpulan orang yang sedang meminumkan (ternaknya), dan ia menjumpai di belakang orang banyak itu, dua orang wanita yang sedang menghambat (ternaknya). Musa berkata: "Apakah maksudmu (dengan berbuat at begitu)?" Kedua wanita itu menjawab: "Kami tidak dapat meminumkan (ternak kami), sebelum pengembala-pengembala itu memulangkan (ternaknya), sedang bapak kami adalah orang tua yang telah lanjut umurnya" ${ }^{\prime \prime 40}$. (QS. al-Qasas:23)

Dalam Islam perempuan tidak dibebani untuk memenuhi kebutuhan keluarga. Akan tetapi seperti disebutkan pada ayat di atas, ketika di dalam sebuah rumah terdapat lansia maka ia harus dipenuhi segala kebutuhannya. Bahkan wanita pun tidak dipermasalahkan keluar rumah demi memenuhi kebutuhan lansia yang terdapat di rumah tersebut.

\section{Berkata dengan baik,lembut, dan sopan terhadap lansia}

Ketika orang tua kita sudah berusia lanjut. Maka mereka akan menggantungkan segala kebutuhan mereka kepada kita. Kitalah satu-satunya orang dekat yang menanggung kehidupan mereka. Kebanyakan orang merasa kesal atau bosan terhadap perilaku orang tua mereka yang sudah lanjut usia. Sehingga kemungkinan besar keluar dari mulut mereka kata-kata yang menunjukkan kekesalan itu mereka lontarkan kepada lansia tersebut.

Lansia dengan kondisi fisik dan psikis seperti di atas cenderung sensitif dan mudah tersinggung atau terlukai hati mereka dengan kata-kata yang sedikit kasar yang dilontarkan kepada mereka ${ }^{41}$. Ketika mereka menerima kata-kata tersebut, mereka akan merasa sempit hati. Mereka merasa bahwa keberadaan mereka adalah beban bagi anaknya. Hal ini dapat mengganggu kejiwaannya.

Dalam hal ini al-Quran menyeru untuk tidak melontarkan sekecil apapun kata yang mengandung kekasaran terhadap orang tua yang sudah lanjut usia. Kita

40 Alquran dan Terjemahnya edisi penyempurnaan, 558.

${ }^{41}$ Dian Hardianti, Jamaluddin Hos, dan Sarpin Sarpin, "Bentuk Dukungan Keluarga Dalam Menjaga Kesehatan Mental Lansia," Jurnal Kesejahteraan dan Pelayanan Sosial 1, no. 2 (t.t.): 138-47. 
dilarang keras untuk membentak mereka. Yang kita lontarkan kepada mereka haruslah kata-kata mulia yang penuh dengan kelembutan. Allah SWT berfirman :

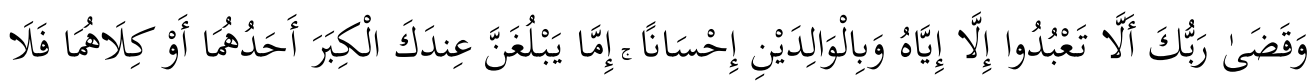

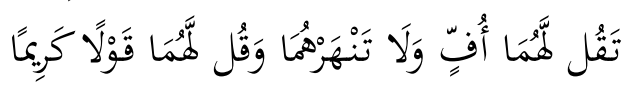

"Dan Tubanmu telah memerintabkan supaya kamu jangan menyembah selain Dia dan hendaklah kamu berbuat baik. pada ibu bapakmu dengan sebaik-baiknya. Jika salah seorang di antara keduanya atau kedua-duanya sampai berumur lanjut dalam pemeliharaanmu, maka sekali-kali janganlah kamu mengatakan kepada keduanya perkataan "ab" dan janganlah kamu membentak mereka dan ucapkanlah kepada mereka perkataan yang mulia." (QS. AlIsra: 23)

\section{Bersikap merendah dan santun terhadap lansia}

Bagaimanapun juga orang lansia memiliki pengalaman hidup lebih banyak dari kita. Wajar kalau kita memuliakan mereka dan bersikap merendah terhadap mereka. Dengan bersikap merendah terhadap lansia, maka mereka akan merasa lebih dihargai. Hal ini memiliki dampak yang baik terhadap psikis mereka di mana mereka memiliki fsisk yang lemah. Sehingga dalam hidup ini mereka merasa dihargai keberadaaanya. Bahkan al-Quran memerintahkan kita agar sikap merendah kita timbul dari rasa kasih sayang terhadap mereka. Allah berfirman :

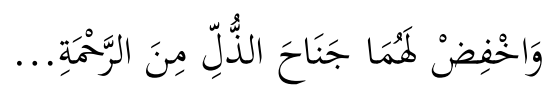

"Dan rendabkanlah dirimu terhadap mereka berdua dengan penub kesayangan..." (QS. AlIsra':24)

\section{Mendoakan}

Perlakuan terhadap lansia tidak hanya berupa sikap fisik saja. Dalam konteks batin pun kita juga harus memperlakukan mereka dengan baik. Allah SWT berfirman :

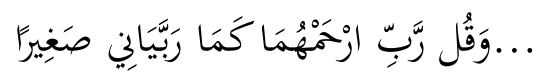

"...dan ucapkanlab: "Wahai Tubanku, kasibilah mereka keduanya, sebagaimana mereka berdua telab mendidik aku waktu kecil". (QS. Al-Isra':24)

\section{Lansia diizinkan tidak mengikuti perang}

Agama Islam adalah agama yang fleksibel. Peraturannya tidak kaku sehingga bisa diterapkan pada setiap keadaan, setiap waktu dan setiap usia. Jihad atau berperang membela agama merupakan kewajiban yang membutuhkan tenaga yang ekstra. Allah mengetahui bahwa semua manusia tidak memiliki kekuatan yang sama. Oleh karena itu dalam hal jihad atau berperang orang yang lanjut usia 
termasuk golongan orang-orang yang diizinkan untuk tidak mengikuti perang. Allah berfirman :

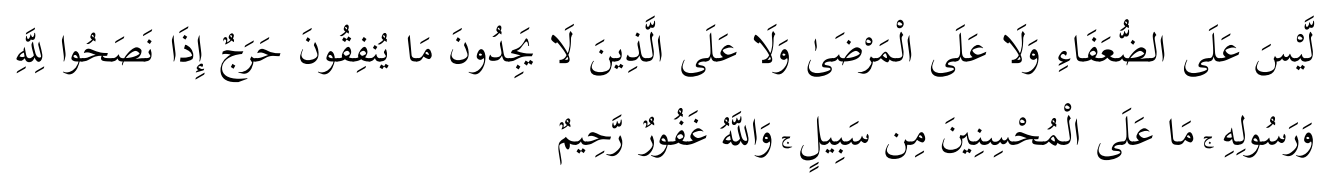

"Tiada dosa (lantaran tidak pergi berjihad) atas orang-orang yang lemah, orang-orang yang sakit dan atas orang-orang yang tidak memperoleh apa yang akan mereka nafkabkan, apabila mereka berlaku ikhlas kepada Allab dan Rasul-Nya. Tidak ada jalan sedikitpun untuk. menyalabkan orang-orang yang berbuat baik. Dan Allab Maba Pengampun lagi Maha Penyayang," (QS. Al-Tawbah:91)

Para ahli tafsir mengatakan bahwa di antara orang-orang yang lemah yang disebut pada ayat di atas adalah orang tua. ${ }^{42}$

\section{Lansia diizinkan tidak mengikuti hijrah}

Hijrah membutuhkan tenaga yang ekstra. Karena orang yang berhijrah akan menempuh perjalanan yang cukup jauh dan akan menghadapi rintanganrintangan dalam perjalanannya. Ketika diwajibkan berhijrah dari Makkah ke Madinah, Allah memberi pengecualian terhadap beberapa golongan yang termasuk di dalamnya adalah lansia. Allah SWT berfirman :

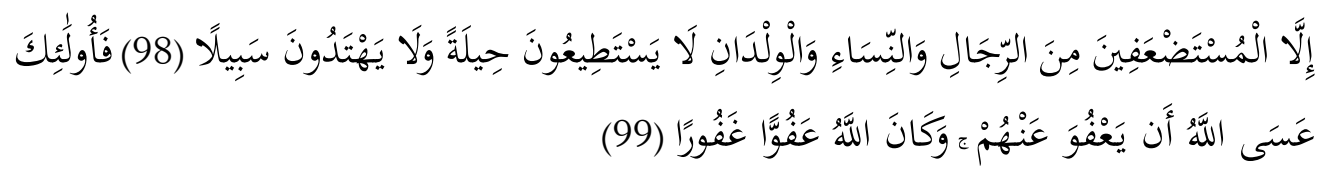

"(98) Ketentuan ini (ancaman tidak melakukan bijrah) tidak berlaku bagi orang-orangyang tidak mampu berbijrah, baik orang-orang lemah, laki-laki, wanita atau anak-anak, yang memang tidak mempunyai kekuatan dan tidak mengetabui jalan keluar untuk. berbijrah. (99) Mereka telah dibebaskan dan diampuni dari siksa tersebut. Mereka, mudah-mudahan, akan memperoleh ampunan. Allah memang sungguh Maha Pemaaf lagi Maha Pengampun. ${ }^{* 3}$ (QS. Al-Nisa:98-99)

Al-Tantawi dan al-Shaukani memberi contoh yang termasuk dari golongan orang-orang yang lemah dalam ayat di atas adalah lansia. ${ }^{44}$

Perlakuan-perlakuan terhadap lansia di atas secara umum menunjukkan bahwa lansia perlu mendapatkan perhatian khusus. Hal ini dikarenakan kondisi fisik dan psikis mereka yang mengalami penurunan tidak seperti manusia normal

\footnotetext{
42 al-Zuhailiy, al-Tafsir al-Munir fi al-'Aqidah wa al-Shari'ah wa al-Manhaj, 5:7-5.

43 Alquran dan Terjemahnya edisi penyempurnaan, 126.

${ }^{44}$ Tantawi, al-Tafsir al-Wasit li al-Qur'an al-Karim, 3:277.
} 
lainnya. Al-Quran mengajarkan untuk memperlakukan mereka dengan penuh penghormatan dan kasih saya kepada mereka sesuai dengan nilai-nilai agama Islam sebagai rahmatan li al-alamin.

\section{Kearifan Lokal Umat Muslim Indonesia Terhadap Lansia}

Dalam memperlakukan lansia umat muslim Indonesia memiliki kearifan lokal yang khas yang mungkin tidak terdapat atau berbeda dengan bangsa lain. Di antara kearifan lokal tersebut adalah :

\section{Penggunaan bahasa khusus dalam berkomunikasi dengan lansia.}

Dalam bangsa Indonesia terdapat salah satu suku yang memiliki sistem bahasa yang cukup unik. Suku tersebut adalah suku Jawa. Di dalam bahasa Jawa ada penggolongan kosakata yang digunakan untuk percakapan terhadap seseorang sesuai kedudukannya. Orang yang baru mempelajari bahasa Jawa akan menganggap bahwa itu adalah 4 bahasa yang berbeda. Padahal semua itu adalah bahasa Jawa yang digunakan dalam keadaan percakapan yang berbeda.

Secara garis besar tingkat tutur bahasa Jawa ada 3 yaitu :

\section{a. Krama (sopan sekali)}

Tingkat tutur krama adalah tingkat yang memancarkan arti penuh sopan santun. Tingkat ini menandakan adanya perasaan segan (pekewub) orang pertama terhadap orang kedua, karena orang kedua adalah orang yang belum dikenal, atau berpangkat, atau priayi, berwibawa, dan lainlain. Murid memakai krama terhadap gurunya. Pegawai menggunakan krama terhadap kepalanya. Pembantu rumah tangga berkrama terhadap majikannya.

Tingkat tutur ini dibagi lagi menjadi 3 yaitu, 1) Muda krama. Tingkatan ini adalah tingkatan yang paling sopan dan hormat, yang biasanya diujarkan oleh orang pertama kepada orang kedua yang berkelas sosial tinggi atau dianggap berkedudukan terhormat, 2) Kramantara. Menurut ketentuan yang dikatakan oleh kebanyakan guru bahasa Jawa, tingkat ini digunakan untuk bercakap dengan kedua yang belum dikenal, atau belum begitu dikenal,dan yang bukan dari golongannya kelas priayi, 3) Wreda karma. Tingkat ini dipakai oleh orang pertama yang telah berusia tua kepada kedua yang berumur muda.

b. Madya (setengah-setengah)

Tingkat tutur madya adalah tingkat tutur menengah antara krama dan ngoko. Tingkat ini menunjukkan perasaan sopan meskipun sedang-sedang saja. Tingkat ini awal mulanya adalah tingkat tutur krama, tetapi dalam proses perkembangannya telah mengalami tiga perkembangan yang penting. Perkembangan itu ialah perkembangan proses kolokiahsasi (informalisasi), penurunan tingkat, dan ruralisasi.. Inilah sebabnya, bagi kebanyakan orang, tingkat madya ini dianggap tingkat yang setengah sopan dan setengah tidak. 
Terhadap orang desa yang dianggap perlu disopani, banyak orang pertama yang mempergunakan madya. Antara teman-teman sekolah yang masih saling berbasa, tingkat madya inilah yang biasanya dipakai. Kepala kantor menggunakan madya kepada rekannya yang muda dan berlatar belakang desa. Terhadap tukang kebun, banyak orang menggunakan madya.

c. Ngoko (tingkat kesopanan rendah)

Tingkat tutur ngoko mencerminkan rasa tak berjarak antara orang pertama terhadap orang kedua. Artinya, orang pertama tidak memiliki rasa segan terhadap orang kedua. Jadi, untuk seseorang yang ingin menyatakan keakrabannya terhadap seseorang orang kedua, tingkat ngoko inilah yang seharusnya dipakai. Orang-orang yang berstatus sosial tinggi berhak pula, atau justru dianggap pantas, untuk menunjukkan rasa tak enggan terhadap orang lain yang berstatus sosial lebih rendah. Ini berarti bahwa seorang majikan berhak memakai ngoko terhadap pembantu rumah tangganya. Guru berhak memakai ngoko terhadap muridnya dan tukang kebun sekolahnya. Ayah dan ibu memakai ngoko terhadap anaknya, menantunya, dan kemenakannya. ${ }^{45}$

Dalam percakapannya terhadap orang yang yang usianya lebih sepuh atau lebih tua, orang Jawa menggunakan krama inggil yang merupakan bahasa yang sangat sopan. Hal ini selaras dengan perintah al-Quran untuk menggunakan perkataan atau bahasa yang baik, mulia, dan halus terhadap orang tua, terutama ketika mereka berusia lanjut.

Budaya seperti ini senada dengan petunjuk al-Qur'an terkait perlakuan terhadap lansia yang disebutkan pada ayat berikut :

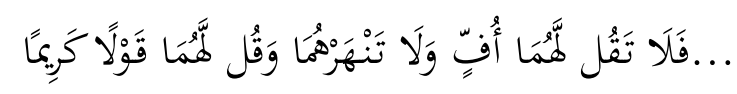

"maka sekali-kali janganlah kamu mengatakan kepada keduanya perkataan "ah" dan janganlab kamu membentak mereka dan ucapkanlah kepada mereka perkataan yang mulia." (QS. Al-Isra';23)

\section{Membungkukan badan ketika berjalan melewati lansia}

Pada budaya di Indonesia khususnya suku Sunda, Jawa, dan Madura, membungkukkan badan merupakan ungkapan kesadaran seseorang terhadap kelas atau tingkatannya. Seseorang mebungkukan badan ketika melewati orang yang lebih tinggi kelasnya atau lebih tua darinya sebagai bentuk atau lambang

\footnotetext{
${ }^{45}$ Soepomo Poedjosoedarmo, dkk., Tingkat Tutur Bahasa Jawa, (Yogyakarta: Kementerian Pendidikan Dan Kebudayaan Badan Pengembangan Dan Pembinaan Bahasa Balai Bahasa Provinsi Daerah Istimewa Yogyakarta, 2013), h. 19.
} 
penghormatan terhadapnya. Hal ini juga merupakan ungkapan penghargaan terhadap keberadaan mereka di tengah-tengah masyarakat ${ }^{46}$.

Hal ini senada dengan nilai-nilai al-Qur'an tentang perlakuan terhadap lansia yang mengajarkan seseorang untuk merendahkan diri di depan orang tua khususnya mereka yang telah masuk pada usia lanjut. Allah berfirman dalam alQuran :

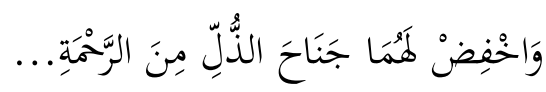

"Dan rendabkanlah dirimu terhadap mereka berdua dengan penub kesayangan ${ }^{47} . . . "$ (QS. AlIsra':24)

\section{Mencium tangan orang yang lebih tua}

Pada budaya Indonesia, sikap mencium tangan juga merupakan suatu ungkapan atau simbol sopan santun dan penghormatan terutama terhadap orang yang lebih tua atau usia lanjut ${ }^{48}$. Mencium tangan dilakukan dengan beberapa langkah yaitu: pertama, seseorang yang hendak mencium tangan membungkukkan badannya di depan orang yang akan dicium tangannya. Kedua, ia mengulurkan kedua telapak tangan dan disambut oleh satu telapak tangan dari orang yang akan dicium tanngannya. Ketika, kedua telapak tangan mendekap satu telapak tangan orang yang akan dicium tangannya. Keempat, mencium tangan dengan posisi semakin membungkuk mengikuti posisi telapak tangan orang yangdicium tangannya. Kelima, membalikkan punggung tangan orang yang dicium sehingga bagian dalam telapak tangan orang yang dicium berhadap-hadapan dengan hidung orang yang akan mencium tangannya. Keenam, mencium bagian dalam telapak tangan $^{49}$.

Budaya mencium tangan sebagai ungkapan penghormatan ini sesuai dengan nilai-nilai al-Quran yang mengajarkan untuk merendahkan diri di depan orang tua terutama yang lanjut usia (QS. Al-Isra':24).

\section{Mendoakan lansia yang sudah meninggal}

Dalam sebagian masyarakat Indonesia dikenal suatu tradisi yang dinamakan tablilan atau yasinan. Pada acara ini tuan rumah mengundang para kerabat dan masyarakat atau tetangga sekitar untuk berkumpul bersama-sama

${ }^{46}$ Metta Rachmadiana, "Mencium Tangan, Membungkukkan Badan: Etos Budaya Sunda, Yogyakarta, Madura," HUMANITAS: Indonesian Psychological Journal 1, no. 2 (31 Agustus 2011): 33-44.

47 Alquran dan Terjemahnya edisi penyempurnaan, 396.

${ }^{48}$ Rachmadiana, "Mencium Tangan, Membungkukkan Badan."

${ }^{49}$ Ade Dasrial dkk., "Konstruksi Pemaknaan Simbolis Salaman Mencium Telapak Dan Punggung Tangan Guru Oleh Santri Ponpes Nurul Yaqin," AL MUNIR: Jurnal Komunikasi dan Penyiaran Islam, 2020, 1-17. 
mendoakan leluhurnya yang sudah meninggal. Sehingga walaupun sudah meninggal, leluhur tetap mendapatkan curahan doa dari keluarga yang ditinggal. Acara tahlilan dimulai sejak hari pertama hingga hari ketujuh orang meninggal dunia. Kemudian di hari keempat puluh, seratus dan seribu juga diadakan. Pada acara tahlilan ini bukan hanya orang yang baru meninggal ketika itu saja yang didoakan. Seluruh arwah leluhur yang telah mendahului pergi ke alam baka juga didoakan apada acara ini ${ }^{50}$.

Tradisi mengirim doa atau mendoakan orang tua ini selaras dengan ajaran al-Qur'an yang memerintahkan untuk mendoakan orang tua. Allah SWT berfirman :

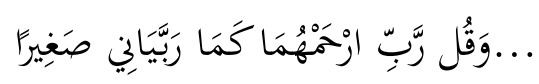

"...dan ucapkanlab: "Wahai Tuhanku, kasibilah mereka keduanya, sebagaimana mereka berdua telah mendidik aku waktu kecil". (QS. Al-Isra':24)

\section{Ziarah terhadap makam leluhur}

Yang juga merupakan implementasi dari QS. Al-Isra':24 di atas adalah tradisi ziarah makam leluhur pada malam Jumlat Legi dan pada hari-hari besar agama seperti idul fitri dan lain-lain. Pada ziarah makam leluhur ini para peziarah membersihkan kuburan leluhur mereka yang sudah meninggal kemudian membaca ayat-ayat al-Quran dan dzikir serta mendoakan para leluhur mereka yang sudah meninggal dunia. Dengan adanya tradisi maka seseorang akan terbiasa mendoakan secara rutin para pendahulunya yang sudah meninggal.

\section{Kesimpulan}

Agama Islam melalui al-Quran menanamkan nilai-nilai kasih sayang terhadap ummat manusia. Di antaranya adalah mengajarkan untuk memberikan kasih sayang terhadap lansia yang mengalami perubahan kondisi fisik dan psikisnya. Perubahan kondisi fisik tersebut berupa kepikunan, daya indera yang melemah (QS. al-Hajj:5), kekuatan tubuh yang melemah (QS. Ar-Rum: 54), uban yang memenuhi kepala, volume suara yang melemah (QS. Maryam: 3-4), dan penurunan fingsi organ reproduksi (QS. Hud:72). Ia juga mengalami kondisi psikis yang cenderung sensitif, cemas, khawatir, dan mudah tersinggung (QS. Maryam: 4-6, QS. Yusuf: 84).

Oleh karena itu al-Quran mengajarkan untuk memberikan beberapa perlakuan kepada lansia seperti membantu memenuhi kebutuhan mereka (al-

\footnotetext{
50 Rhoni Rodin, "Tradisi Tahlilan dan Yasinan," IBD A: Jurnal Kajian Islam dan Budaya 11, no. 1 (2013): 76-87.
} 
Qasas: 23), bertutur kata sopan dan lemah lembuh, merendahkan diri, dan mendoakan mereka (QS. al-Isra: 23-24). Al-Quran juga memberikan keringanan hukum bagi lansia seperti diizinkan untuk tidak mengikuti perang (al-Tawbah: 91) dan tidak mengikuti bijrah (QS. Al-Nisa': 98-99).

Dalam hal ini, masyarakat Indonesia melalui kearifan lokal mewujudkan nilai-nilai al-Quran tersebut dalam bentuk tradisi dan budaya. Tradisi dan budaya tersebut meliputi : pertama, tradisi menggunakan bahasa krama inggil dalam berkomunikasi dengan lansia; kedua, membungkukkan badan ketika lewat di depan lansia sebagai penghormatan dan pengakuan keberadaan mereka; ketiga, mencium tangan lansia ketika bersalaman; keempat, tradisi tablilan untuk mendoakan lansia yang telah meninggal dunia; dan kelima, tradisi ziarah makam leluhur untuk mendoakan lansia di kuburan mereka.

\section{Bibliografi}

Aji, Mujib Hendri, Muhammad Zainul Hilmi, dan M. Taufiq Rahman. "The Living Qur'an as a Research Object and Methodology in the Qur'anic Studies." Jurnal Iman dan Spiritualitas 1, no. 1 (2021): 78-84.

Al Mubarroh, Nadya Ristamida, Indra Himawan Susanto, dan Yetty Septiani Mustar. "Aktivitas fisik dan aspek kekhawatiran lansia pada masa pandemi Covid-19." Altius: Jurnal Ilmu Olahraga dan Kesehatan 10, no. 1 (2021): 97 111.

Asfahani (al), Raghib (al), al-Mufradat fi Gharib al-Qur'an. Mekkah: Maktabah Mustafa Nizar al-Baz,

"Bina'al-Fiqh al-Hajj al-Muyassar." Diakses 3 September 2021. https://scholar.google.co.id/citations?view_op=view_citation\&hl=id\&u ser=XGUYN5YAAAAJ\&citation_for_view=XGUYN5YAAAAJ:d1 gk VwhDp10C.

Dasrial, Ade, Sarmiati Sarmiati, Afrizal Afrizal, dan Zainal Zainal. "Konstruksi Pemaknaan Simbolis Salaman Mencium Telapak Dan Punggung Tangan Guru Oleh Santri Ponpes Nurul Yaqin.” AL MUNIR: Jurnal Komunikasi dan Penyiaran Islam, 2020, 1-17.

Dawud, Abu. Sunan Abi Dawnd. Beirut: Dar Ibn Hazm, 1997.

Halaby (al), Samin (al). Umdat al-Huffad₹. Beirut: Dar al-Kutub al-'Ilmiyyah, 1997.

Hanbal, Ahmad ibn. Musnad al-Imam Ahmad ibn Hanbal. Vol. 41. Beirut: Mu'assasah al-Risalah, 1995.

Hardianti, Dian, Jamaluddin Hos, dan Sarpin Sarpin. "Bentuk Dukungan Keluarga Dalam Menjaga Kesehatan Mental Lansia.” Jurnal Kesejabteraan dan Pelayanan Sosial 1, no. 2 (t.t.): 138-47. 
Jajasan Penjelenggara Penterdjemah/Pentafsir Al-Qoeraan (1967). Alquran dan Terjemahnya edisi penyempurnaan. Lajnah Pentashihan Mushaf Al-Qur'an, 2019.

Kumi (al), Ahmad Sayyid, dan Muhammad Ahmad Yusuf Qasim (al). al-Tafsir alMawdu'i li al-Quran al-Karim, 1982.

M. Mansyur, ed. Metodologi penelitian living Qur'an \& Hadis / M. Mansyur. Yogyakarta: TH-Press [u.a.], 2007.

Maladi, Yasif. Makna dan Manfaat Tafsir Maudhu'i. Prodi S2 Studi Agama-Agama UIN Sunan Gunung Djati Bandung, 2021.

Manzur, Ibnu. Lisan al-'Arab. Kairo: Dar al-Ma'arif,

Maulidah, Evi. "Pendidikan Anak Usia Dini Menurut Al-Qur'an Dalam Kajian Tafsir Maudhu'i." Childhood Education: Jurnal Pendidikan Anak Usia Dini 2, no. 2 (2021): 170-82.

Poedjosoedarmo, Soepomo, dkk., Tingkat Tutur Bahasa Jawa. Yogyakarta: Kementerian Pendidikan Dan Kebudayaan Badan Pengembangan Dan Pembinaan Bahasa Balai Bahasa Provinsi Daerah Istimewa Yogyakarta, 2013.

Qurtubiyy, Muhammad al-. al-Jami' li Ahkam al-Qur'an. Vol. 6. Kairo: Dar alHadith, 2007.

Rachmadiana, Metta. "Mencium Tangan, Membungkukkan Badan: Etos Budaya Sunda, Yogyakarta, Madura." HUMANITAS: Indonesian Psychological Journal 1, no. 2 (31 Agustus 2011): 33-44.

"Ramah, Identitas Indonesia di Mata Dunia." Diakses 3 September 2021. https://www.goodnewsfromindonesia.id/2018/07/25/ramah-identitasindonesia-di-mata-dunia.

Razi (al), Fakhruddin Muhammad. al-Tafsir al-Kabir aw Maaftih al-Ghayb. Vol. 23. Kairo: Maktabah Tawfiqiyyah, _.

Rodin, Rhoni. "Tradisi Tahlilan dan Yasinan." IBDA: Jurnal Kajian Islam dan Budaya 11, no. 1 (2013): 76-87.

Salafudin, Ahmad Basith. "Studi Living Qur'an: Tradisi Pembacaan Surat AlWaqi'ah Di Pondok Pesantren Darul-Falah Tulungagung." Al-Drikra: Jurnal Studi Ilmu al-Qur'an dan al-Hadits 15, no. 1 (2021): 111-38.

Simamora, Tia Subu. "Tradisi Pembacaan Yasin 41 Studi Living Qur'an.” Jurnal El Thawalib 2, no. 2 (2021): 1-14. 
Sucipto, Sucipto, dan Fajar Rinawati. "Perbedaan Depresi Lansia di Pondok Lansia dan Lansia di Posbindu." Jurnal Ilmiah Permas: Jurnal Ilmiah STIKES Kendal 11, no. 1 (2021): 43-48.

Tantawi, Muhammad Sayyid. al-Tafsir al-Wasit li al-Qur'an al-Karim. Vol. 9. Kairo: Dar al-Sa'adah, 2007.

Winarni, Sri, Djoko Nugroho, dan Farid Agushybana. "Dasar Kesehatan Reproduksi," t.t.

Yanti, Meyi, Alkafi Alkafi, dan Defi Yulita. "Senam Lansia terhadap Tekanan Darah pada Lansia Hipertensi." JIK (Jurnal Ilmu Kesehatan) 5, no. 1 (2021): 44-52.

Zuhaily, Muhammad Wahbah al-. al-Tafsir al-Munir fi al-'Aqidab wa al-Shari'ah wa al-Manhaj. Vol. 6. Damaskus: Dar el-Fikr, 2003. 